\title{
Intelligence and Creativity: Epistemological Connections and Operational Implications in Educational Contexts
}

\author{
Carla Luciane Blum Vestena', Juliana Berg², Weslley Kozlik Silva ${ }^{3}$, Cristina Costa-Lobo ${ }^{4}$ \\ ${ }^{1}$ Productivity Scholarship from the F.A. UFPR/UNICENTRO, Brazil \\ ${ }^{2}$ Scholarship Holder CaPes, UFPR, Brazil \\ ${ }^{3}$ Federal University of Paraná \\ ${ }^{4}$ Institute of Higher Studies in Fafe, Portugal \\ Email: cvestena@unicentro.br, bergjuliana@gmail.com,weskozlik@hotmail.com,cristinalobo@iesfafe.pt
}

How to cite this paper: Vestena, C. L. B. Berg, J., Silva, W. K., \& Costa-Lobo, C. (2020). Intelligence and Creativity: Epistemological Connections and Operational Implications in Educational Contexts. Creative Education, 11, 1179-1200.

https://doi.org/10.4236/ce.2020.117088

Received: June 17, 2020

Accepted: July 27, 2020

Published: July 30, 2020

Copyright $\odot 2020$ by author(s) and Scientific Research Publishing Inc. This work is licensed under the Creative Commons Attribution International License (CC BY 4.0).

http://creativecommons.org/licenses/by/4.0/

\begin{abstract}
In a theoretical essay, the main theories that relate intelligence and creativity are revisited, presenting epistemological connections and operational implications in their educational contexts. In this sense, this study presents subsidies for the understanding of how its historical construction for thinking about cognition occurred, composing a synthesis of important theoretical framework for later studies. In addition to these contributions, it brings recent discoveries, such as the fact that there is a need for a certain intellectual level in order to establish creative thinking and points to a systemic perspective as being a possible path for cognitive science, assuming that in the future studies should transcend this ideal aiming for quantum thinking or for the alignment of elements not yet understood in consciousness and in existence itself. In this sense, it exposes how much public policies in education need to evolve towards the development of integral citizens capable of creativity and aware of their intellectual rights. Lastly it is believed that both intelligence and creativity have an epistemological connection capable of directly affecting educational contexts, resulting in education founded on a new paradigm of thinking.
\end{abstract}

\section{Keywords}

Intelligence, Creativity, Epistemology, Education

\section{Introduction}

Intelligence and creativity are concepts that have attracted the interest of the researchers, because they have a huge direct impact on the potential ability of an 
individual to do something for his/her wellbeing and school performance. However, these studies were not consistent, since, according to Runco (2014), there was no clear distinction between intelligence and creativity and the research did not correlate them with the empirical evidence up to 1962, when Getzels and Jackson began their investigations.

According to Runco (2014), Wallach and Kogan (1965) discussed Getzels and Jackson's (1962) method, using the concept of divergent/convergent thinking and the influence of context. They conceived their own method, consisting of open tasks that questioned the usefulness of multiple objects. This enabled them to follow the modes of thinking of small children, concluding that "the implication is that IQ, grade point average (GPA), and the convergent thinking that is required of them is independent of divergent and original thinking" (Runco, 2014: p. 3).

Both concepts had a negative connotation, since creativity referred to psychopathological characteristics that showed deviations of normality (Fink et al., 2012). Investigations about intelligence mainly regarded deficit and school failure (Funham et al., 2008). These concepts used to be considered in a pejorative manner, however, due to progress in cognitive and positive psychology there was a growing interest in the domain of intelligence and creativity, provided individual positive qualities (Krentzman, 2013). Currently, intelligence is evident as one of the most prestigious traits by society (Faria, 2007). The concept of creativity, as a psychological trait, has gradually acquired a significant importance for human development (Nakano et al., 2015). According to Ward (1994) the ability to produce new knowledge is intrinsic to human beings and is one of the most prominent aspects of human cognition.

The predisposition of individuals to engage in invention and understanding allows them to interact and transform the world. This is the most primitive form of realization that encourages us to discover and learn ever more (Getzels \& Csikszentmihalyi, 1976). Intelligence and creativity are grounded concepts. However, they generate controversy over their definitions (Furnham et al., 2008; Silvia, 2008a).

Recent studies question whether creativity develops more than intelligence during divergent thinking since these tasks typically require fluency in conflict or problem resolution and the number of novel ideas is greater (Runco \& Acar, 2012; Karwowski et al., 2016; Kim, 2008; Forthmann et al., 2019). In the last year, studies conducted in Germany have investigated the quality of ideas and of creativity itself. Forthmann et al. $(2019,2017)$ suggest that creative quality can be measured by assessing three classic dimensions-originality, distancing and quickness of mind. In this respect, a method was proposed to investigate the multidimensionality of tasks involving divergent thinking, applying IRTree modeling (De Boeck \& Partchev, 2012).

Forthmann et al. (2019) believe it is possible to have a different view "of the relationship between fluency and classifications of creative thinking", since, in 
contrast to classic factorial analysis approaches that measure the quality-quantity relationship, it allows a debate on the discriminant validity of fluency and originality, measuring the quality-quality relationship "for high production and low ideational sets of production within two common important instructions". Thus, the relationship between the concepts investigated in terms of understanding creativity tends towards testing the multidimensionality of tasks involving divergent thinking, exhaustion and motivation, which are also qualitative and capable of proving, based on certain variables, how creativity performs better in mixed relations tests (Runco \& Acar, 2012; Karwowski et al., 2016; Kim, 2008; Forthman et al., 2019).

\section{Relationship between Intelligence and Creativity}

In the literature, three models stand out because they present different perceptions about the concepts of intelligence and creativity. The first model argues for the existence of a strong correlation between creativity and intelligence. In this perspective, individuals who have the capacity to carry out abstract reasoning also have the skills to develop innovative ideas (Sternberg, 2001). According to the second model, creativity and intelligence are independent concepts, so that someone does not need to have high cognitive abilities to be able to reveal his/her creativity (Getzels \& Jackson, 1962). This suggests that there are other factors besides IQ that can determine creative potential (Kim et al., 2006). The third model is based on the principle that the relationship between creativity and intelligence is not linear. Kaufman (2015) stated that creativity is an integral part of intelligence, as opposed to the notion that creativity refers to a different concept of intelligence. Most of the studies in this field tend to assume a generalist perspective of intelligence, and to advance research, they resort to the use of tests directed to the group "g", while for the study of creativity they use tests of divergent thinking. In these circumstances intelligence and creativity have a low but significant correlation level (Barron \& Harrington, 1981, quoted by Kaufman 2015). However, many theorists claim that these two concepts have a closer relationship than these studies indicate. Specifically, Silvia (2008a, 2008b) suggests that this relationship is underestimated because the studies are limited only to the analysis of observable results, that is, to performance in an intelligence test.

Jung (2014) argues that intelligence can be viewed as the problem-solving capacity of everyday life, while creativity can translate the subject's skills to solve less common problems. Other perspectives argue that creativity and intelligence are both cognitive functions (Silvia, 2015) or that divergent thinking is simply an executive cognitive function (Anthony et al., 2007).

Much of the work in the fields of creativity and intelligence focuses on fluid intelligence and not on the "g" factor or crystallized intelligence. Researchers (Arendasy et al., 2014) devoted themselves to the study of the executive functions underlying divergent thinking and fluid intelligence. They found that the ability to identify small changes, called updating (Friedman \& Miyake, 2012), allows for the prediction of both divergent thinking and fluid intelligence, as well 
as the ability to repress a natural response-inhibition-allowed for predicting divergent thinking. Additional studies (Beaty \& Silvia, 2013) used the creation of metaphors to measure creativity, and also pursued the analysis of constituents of the Cattell-Horn-Carroll (CHC) model, instead of focusing only on the " $\mathrm{g}$ " factor achieving to establish numerous relations between creativity and intelligence, contrary to what previous studies had verified.

Silvia (2015) concluded that the relationship between fluid intelligence and creativity is mediated by other cognitive mechanisms. Nusbaum and Silvia (2011) found that fluid intelligence produces a substantial effect on creativity as well as acting as a more efficient strategy to improve outcomes. Other authors (Beaty \& Silvia, 2013) based on a longitudinal study of divergent thinking, concluded that the elements of the sample with higher levels of fluid intelligence started by transmitting creative ideas, but over time this ease of evocation diminished. On the contrary, participants classified with low fluid intelligence experienced initial difficulties in expressing creative ideas, but there was a positive evolution over time. We have noticed that the state-of-the-art does not seem to suffice to make the relationship between intelligence and creativity secure. These concepts have a close connection with several cognitive and situational mediators. It may be instinctively attractive to consider them as completely distinct concepts. However, there is evidence that this divergence may negatively interfere with the children being evaluated (Kaufman, 2013). Although they stand out as important concepts that contribute to a better understanding of human functioning, it is worth noting that there is a huge deficit in the existence of tests that try to evaluate intelligence and creativity simultaneously.

A recent study by Oliveira and Vestena (2017) covers 46 master and doctoral studies about gifted and gifted subjects, which were accomplished from 2000 to 2013, according to data available in the BDTD/IBICT/Cnpq database. The same study verified 62 scientific articles published between 2001 and 2014 in Brazil. The authors concluded that only $3 \%$ of articles and $0 \%$ of theses and dissertations deal with creativity and/, or creative process gifted Brazilian students. In spite of the progress that has been made (Nakano et al., 2011; Oliveira \& Vestena, 2017), there is still a large gap in the amount of tests that evaluate this aspect. Despite the difficulties in defining and evaluating creativity, several intervention programs have been implemented with a view to promoting creativity. Such programs consist in full stimulation of the creative potential of the participants, assumed as a highly valued capacity nowadays. It should be noted that all interventions in the field of creativity are based on two guiding principles: all individuals can be creative and creativity is a capacity that can be stimulated.

According to the first principle that "(...) all individuals have creative potential (...)" Vygotsky (1990) stated that creativity is an intrinsic characteristic of the human being, yet not everyone has the same opportunities to develop this ability. The individual characteristics (Martindale, 1999) and the sociocultural context decisively influence the development or inhibition of creative potential. Studies have shown that more creative people have greater physiological (Mar- 
tindale, 1999) and emotional sensitivity (Valentim et al., 2014; Neumann \& Vestena, 2016).

Intelligence can influence creative ability. Considering the Threshold Theory (Barron, 1969, quoted by Bahia, 2008) these two dimensions, creativity and intelligence, are associated only if the individual is below a certain level of intelligence. In short, if the subject manifests a very high intelligence it may be an impediment to his creative expression. As we have stated before, some authors, such as Guilford (1967), defend the perspective that creativity is an integral part of intelligence. But there are those who argue that intelligence is itself a component of creativity (Sternberg \& Lubart, 1991). Other theorists believe that intelligence and creativity correspond to the same phenomenon (Haensly \& Reynolds, 1989), while authors such as Getzels \& Jackson (1962) argue that they are independent phenomena.

Emotions can also influence the creative capacity, since the giftedness does not refer exclusively to rational aspects. The conditions for the interrelated development of the intellectual, emotional, and social aspects of the gifted have been one of the growing concerns of education (Neumann \& Vestena, 2016). For this reason, studies for examples for these programs, see: 1) on emotions in giftedness such as the sensitivity and intensity of emotions, effects of negative events, stressors, superexibility and developmental transitions of life (Peterson, 2014) have been diverse; 2) anxiety, emotional intensity and overex-ability (Guignard \& Zenasni, 2009); 3) sense of identity, friendship management, empathy, sense of humor, intensity of emotions, perfectionism, moral sensitivity and ethics (Gross, 2014); 4) spirituality in adulthood, stress and anxiety (Kane \& Silverman, 2014); 5) stress management, adaptability, mood, interpersonal and intrapersonal intelligence (Gómez, 2010); 6) self-concept and self-esteem (Padilla, Hogan, \& Kaiser, 2007) and 7) interaction of emotions and cognition (Cunha, 2011; Valentim et al., 2014).

The literature often reports that the medium does not contribute to the stimulation of creative potential. On the contrary, Oliveira \& Vestena (2017) noted that the creative process of the gifted is closely linked to autonomous moral judgment because they manage to articulate actions, consequences and intentions before thinking about solutions with fluency and flexibility. Such characteristics are the result of reversible thinking, in which they correct their own hypotheses and create different possibilities for deliberating on the problem. Creativity is related to the characteristics of logical thinking and reflective abstraction, which allows for fluency, flexibility, originality. The students who were the subjects of this research had the curiosity and courage to take risks and create (Reis et al., 2004, Torrance, 1965; Sternberg, 2008), and these are characteristics of people with giftedness and talent the productive-creative type), as they allow for innovative actions, with plenty of detail.

The fact is that emotions are not excluded from the cognitive process, but the cognitive process can be neglected when emotions are not given proper attention (Neumann \& Vestena, 2016). Since, "affectivity is the precursor spring of intelli- 
gence" (Piaget, 1932) and is not isolated from creativity, because the creative process enhances intelligence and vice versa, this occurs in the social realm of exchanges between people and permeated by Emotions. This is what allows the expansion and amplitude of knowledge and the act of creation and innovation manifests itself in this way (Oliveira \& Vestena, 2017).

Developing creativity is a challenging process because it is extremely complex for individuals to abandon their beliefs and change their habits. It is safer to stay in our comfort base, where the margin of error is minimal and where the risk is zero. Situations such as: the fear of failure, the security of the known, the search for perfection, the fear of risk are examples of obstacles that impede the promotion of creative potential (Watts, 1967, quoted by Bahia, 2008). In the educational context, these difficulties are sometimes reinforced. Students tend to be encouraged to conform, since teaching is structured to deal with all students in the same way, that is, it does not promote the development of curiosity, it does not deepen the interests and potentialities of each student. On the contrary, the idea is defended that all young people should be included in the norm (Amabile, 1996).

Therefore, if the basis of creativity refers to the discovery and attribution of a meaning proper to our personal experiences (Powell, 1994) and if all people have the possibility to develop their creative potential, it is crucial that development programs of creativity provide conditions for the belief that all human beings are potentially creative.

According to the second principle "Creativity is stimulated", in order to stimulate creative potential, it is essential to invest in its development, just as it is essential to train, so that this capacity is not lost (Guenther, 2000). Creativity must be perceived, as an ability shared by all individuals that promotes personal and social well-being. Often, creative ability is considered a secondary domain, especially when we refer to the Educational System. At school, one only invests in creativity when all the alternatives, considered more adequate and meritorious, have been implemented, and these have failed. However, it is important to stress that creativity should not only be included in all curricular areas but should be a competence developed in all educational activities. It is concluded, therefore, that creativity as well as being a relevant domain is of enormous importance in the educational context (Bahia \& Moreno, 2007).

Creativity is a key aspect of gifted education (Piske et al., 2016a). But the challenge of promoting education that includes creative educational practices is something that is present in many schools (Piske et al., 2014; Stoltz, 2016). Piske (2016) explains that such practices may be linked to teacher training that needs to be prepared to meet the needs of its students, especially those with high skills, because these students need a school that can meet their special needs and develop their Potential creativity.

The current educational reality in Brazil can be considered a barrier to the development of creativity in school (Piske et al., 2016b). Despite the implementation of these programs, the authors continue to argue that creativity has been 
underestimated (Plucker et al., 2004; Oliveira \& Vestena, 2017). This criticism becomes more acute when one recognizes that it is the ability to innovate and create that provides progress in knowledge. For example, creativity is a little exercised in school, so Torrance (2001) argues that the absence of creative thinking is the biggest gap in teaching. Indeed, the educational and family context itself hampers and may even inhibit the development and expression of creative capacity as parents and teachers advocate social conformism (Albert, 1996). It is evident there are several factors that are fundamental to the development of creativity (Powell, 1994). Fleith and Alencar (2005) demonstrate the relevance of five factors: listening to the ideas of others; Awareness of their own creativity; Curiosity for knowledge; Autonomy, that is, to show determination to invest in what is "new" and a willingness to produce innovative ideas.

It is imperative that gifted students recognize themselves as creative (Guilford, 1967; Torrance, 1965), because they are innovative, fluent, and flexible; however, the awareness of creativity by the gifted requires moral conscience (Oliveira \& Vestena, 2017). The development of moral consciousness enables gifted students to devise divergent thinking. Teachers need to observe gifted students and give voice to their moral and affective conceptions Valentim et al. (2014) are emerging imperatives in today's society, where the goal is to provide a school educational environment in which students can create and recreate knowledge. From a cooperative learning environment, gifted students develop autonomy, that is, they are able to decentralize themselves to have a relation of balance with "the social", placing themselves in a position of otherness. The gifted student can now recognize that it is the equilibrium of his own adaptation and the realization of the social equilibrium that he effected Piaget (1918).

Oliveira and Vestena (2017) analyze the creative process of gifted students through the Piagetian perspective and realize that the functions of thought such as reversibility, abstraction, associativity and compositions are imperative conditions for the creation process. The authors understand that this is not only in order to create innovations as technological gadgetry, but knowledge as clever solutions to everyday conflicts and management of interpersonal relationships. These more complex thoughts are drawn from past experience (Piaget, 1986), later these elements complicate the extent that mental operations become more reflective, that is, associative, abstract and extension. Creativity is the result of the ability to interpret data, create hypotheses and make deductions in a flexible and articulated way with the information of everyday experiences (Oliveira \& Vestena, 2017).

\section{Creativity and IQ Tests: Possibilities, Realities and Ironies}

Although the area of creativity is being investigated in depth and being an extremely productive domain is still considered a controversial topic. The most common evaluation of creativity refers to divergent thinking, and the most widely used instrument to measure this concept is the Torrance Tests of Creative Think- 
ing (Torrance, 2008). This test contemplates fluency, flexibility and originality. The question arises: can a subtest that measures divergent thinking (creative fluency) be added to an IQ test? Instead of asking participants to register many elements of a category (for example, types of flowers), we could ask open questions (for example, what could happen if people had the ability to fly). Certainly, it would be possible to account for these responses in order to determine fluency, however, the examiners of IQ tests are highly trained as to what constitutes a right or wrong response and the same applies to examiners of creativity tests, namely TTCT, they can easily determine whether a response is relevant (which can be accounted for in the fluency parameter) or irrelevant (Kaufman, 2009). The same applies to the evaluation of originality, since this test has an array of responses in which points are awarded based on the production of rare ideas that deviate from the obvious. Implementing this inclusion in the IQ tests would not imply significant changes to the process (Hass, 2015). Basing the evaluation of creativity only on the evaluation of divergent thinking is very reductive in that it is only an aspect of creativity (Cramond \& Torrance, 2002). Including evidence of divergent thinking in IQ tests would be the simplest possibility, but not necessarily the most sensible decision. Indeed, if one of the criticisms of IQ testing is that it has stagnated for the last century (Sternberg \& Kaufman, 1996, quoted by Kaufman, 2015), it would be imprudent to select a dimension of creativity that has already been consolidated More than six decades. This could not be considered a breakthrough. Another measure that evaluates creativity is the consensual evaluation technique (Amabile, 1996; Baer \& Kaufman, 2012). It consists in the realization of tests that evaluate creative products translators of different areas of knowledge. This has to be done by judges familiar with the task they evaluate. Such familiarity will give them the possibility of a necessary consensus on a product, even if the criterion of evaluation is the appeal to their subjective perception of creativity. This method would be impracticable on a large scale, for reasons of time and cost, however, it would be beneficial if it were implemented on a larger scale. To do so, we can use programming data, i.e., computer content, which perform tasks previously performed only by humans. In this way, the computers would be the indicated tool to evaluate the creative work (ex: creative writing). However, the question arises: how can we leverage computers? Nowadays, the current systems have only been directed toward the evaluation of writing. It would be advantageous if, in addition to writing, these programs had the ability to evaluate creativity. There are many facets to determine the quality of writing, so informative software for creative evaluation would have to identify which components of creativity and to what extent promote it. Although we have focused on creative writing, the consensual evaluation technique has been used in many other domains, for example: photography (Dollinger, 2007), music (Priest, 2006), science (Kaufman, 2009), basically to evaluate all Problems (Mumford \& Reiter-Palmon, 1998, quoted by Kaufman, 2015). It should be noted that the classification of different creative products that fall into the same do- 
main tend to obtain coherence between the subjects (Baer, Cole, \& Kaufman, 2009; Baer, Kaufman, Lee, \& Lee, 2007). In order to reach a broad perspective on creativity, it is fundamental to evaluate different domains. Although it is simpler to evaluate creativity from a general domain, the relevance of a domain-specific evaluation has been verified (Baer \& Kaufman, 2006; Baer et al., 2009; Kaufman, 2012). Unfortunately these procedures are very costly, minimizing the willingness to take risks. Some older tests may allude to creativity as a general domain, but most do not address any domain-specific assessment. This is understandable in that IQ tests are a business which entails costs and especially involves fear of taking risks. Ironically, what prevents the inclusion of evidence of creativity in the IQ tests is the very lack of creative ability of the authors of these batteries.

\section{Model of Guilford's Intellect Structure}

Guilford's Model of Intellect's Structure (Guilford, 1967, quoted by Kaufman, 2015) rests on a cognitive perspective of intelligence. Therefore, it emphasizes three crucial dimensions: operations, content and products (Batey \& Furnham, 2006; Prieto, 2006; Sternberg \& O'Hara, 2009). The operations translate into an intellectual process that the organism accomplishes with the information it receives. It contemplates cognition, memory, divergent production, convergent production and evaluation; the content includes components of a figurative, symbolic, semantic and/or behavioral character and, finally, products occur in the form of units, classes, relations, systems, transformations or implications (Sternberg \& O’Hara, 2009; Wechsler, 2008). Guilford's Intellectual Structure Model represented a pioneering step in the study of creativity. This was the starting point for the introduction of the concepts of divergent thinking and convergent thinking, which currently constitute much of the theories of creativity. According to Guilford, there are three key components of creativity: fluency, flexibility (proposals of different categories of ideas) and originality (generating unusual or non-standard solutions). These are the cognitive indicators related to divergent thinking. According to Guilford (1950, quoted by Kaufman, 2015), divergent thinking is a fundamental capacity for stimulating creativity. Through divergent thinking, the person will be able to produce several ideas, which will translate into different possibilities. The divergent thinking tests allow to calculate the quantitative index of fluency, the number of ideas generated.

\section{Torrance Educational Model}

Torrance motivated by the results that Guilford had obtained in his investigations on creativity and divergent thinking, began to take an interest in the area giving rise to a vast bibliographical production. According to Torrance, when we are faced with a problem, we begin by looking at it from different perspectives in order to formulate hypotheses that allow its resolution. The creative process thus emerges (Wechsler, 2008). This moment, in which innumerable ideas and spontaneous solutions emerge, in which one tries to arrange multiple alternatives to 
solve the problem in a different and original way is promoted by the divergent thinking (Wechsler, 2008). However, when the various hypotheses are assimilated, convergent thinking becomes remarkable, synthesizing all the proposals in order to select the idea that seems most logical, rational and effective to reach the solution of the problem (Wechsler, 2008). However, the final stage is the essence of the creative process. The communication of the obtained results is determinant and characterizes like the main stage of the whole process. It is only through the communication of results that individuals can gain insight into whether or not there were flaws in the creative process. If so, it will need to be returned to the creative process. Torrance is an invaluable reference in the study and development of creativity, providing a tremendous contribution in the field by designing its famous Torrance Creative Thinking Test, which has become the most widely used test to evaluate this aspect (Prieto, 2006). The author who has propelled the history of creative education considers that every human being has creative potential, so this competence must be stimulated and not relegated to the background to the detriment of other human capacities or characteristics.

\section{Sternberg and Lubart Creative Investment Model}

Sternberg and Lubart's $(1991,1995)$ creative investment theory consists of a confluence approach, and highlights that effectively creative individuals are those who are willing to "buy low and sell high", that is, pursue ideas that are not valued Or even recognized by others; And then try to convince them of their value; If they are successful, their ideas will automatically be valued. In this way, the creative subject will sell it at a high price, consequently passing on his idea to others, then moving towards a new idea. Sternberg and Lubart's creative investment theory conceives creativity according to a multidimensional perspective (Sternberg \& Lubart, 2009), which contemplates six distinct but interlinked resources, namely: intellectual skills, knowledge, cognitive styles, Personality, motivation and the environment (Sternberg, 2008). These components are indispensable for the exteriorization of creativity. We are interested in promoting the succinct discussion of each of the resources mentioned above. With regard to intellectual abilities, the preponderance of three abilities stands out-the synthetic ability gives the individual the ability to solve problems sui generis; The analytical ability allows the subject to select the ideas that will be effectively feasible and that must be monetized; The practical-contextual ability refers to the ability to persuade the other to invest in their idea (Sternberg \& O'Hara, 2009; Sternberg et al., 1997). Individually, each of these abilities also produces results. Specifically, in the absence of the other two skills, analytical and practice-contextual, synthetic ability fosters the ability to generate new and profitable ideas; Analytical ability stimulates critical thinking, but not creative thinking; In relation to practical-contextual ability, can result in the social acceptance of ideas, not so much due to the quality of the ideas presented, but also to the efficiency in the dissemination and presentation of ideas. Thus, holding knowledge in the area is 
another of the main resources to achieve progress in the development of creativity. On the other hand, knowledge in a particular domain can result in a closed and rooted view, since the subject does nothing to change his or her way of observing the situations he has experienced in the past with other experiences. Therefore, knowledge can promote or impair creativity. Cognitive styles emphasize individuals' preference for following their own thoughts, not subjugating themselves to the will and opinion of others (Sternberg \& O'Hara, 2009; Sternberg et al., 1997). Regarding styles of thought, it should be pointed out that a legislative style is particularly important for the expression of creativity (Sternberg, 1988, 1997b). Individuals who manifest a style of legislative thinking like to create rules, structure, plan, and formulate solutions. The results of the investigations (Sternberg \& Grigorenko, 1995; Sternberg et al., 1995) indicate that subjects who present a legislative thought tend to show a more productive academic performance compared to colleagues who do not manifest this way of thinking; However, if the school does not value or devalue creativity effectively, its academic performance is surely compromised (Oliveira \& Vestena, 2017). Also the personality is a determining resource for the expression of the creative process. It is essential that the individual has traits such as self-efficacy, desire to overcome challenges, taste for unknown situations and tolerance to ambiguity (Sternberg \& Lubart, 2009). Motivation is also extremely important. In particular, intrinsic motivation, because a person that does not have intrinsic motivation will hardly be able to develop his creative spirit, or will not be able to overcome decisive obstacles decisive to achieve creative productivity (Sternberg \& O’Hara, 2009; Sternberg et al., 1997). Finally, it is important to highlight the relevance that the sixth appeal presented by Creative Investment Theory, the environment, assumes in the expression of creativity-safe and welcoming spaces foster the development of creative ideas. Regardless of the relevance granted to these resources. Sternberg and Lubart (2009) argue that, creativity is not only the sum of all of them, there is the possibility of something else being involved. Thus, with regard to the confluence of these six resources, there is the hypothesis that creativity involves more than a simple sum of these resources. This is because some individuals may reveal limitations in some of the resources; However, this limitation can be partially offset by the manifestation of higher levels in other resources, neutralizing the weaknesses in the most fragile resource(s); And there may still be interactions between the different resources, so high levels in different resources can enhance creative capacity.

\section{Csikszentmihalyi's Systemic Vision}

Csikszentmihalyi (2014) introduced the vision of systems by reformulating the basic question from "What is creativity?" to "Where is creativity?" Rather than considering creativity as an intrinsic attribute of certain artefacts, Csikszentmihalyi (2014) argued that judgements of creativity emerge through three interactive components: 1) the domain, or body of knowledge that exists in a particular 
discipline and at a specific moment; 2) the individual, who acquires knowledge of the domain and produces variations to the existing knowledge; and 3) the field, consisting of other specialists and members of the discipline who decide which of the novelties produced by all the individuals that work in this discipline deserve to be preserved for the next generation. The systematic vision of Csikszentmihalyi (1996) has many advantages, particularly in its conceptual richness, but also exhibits possible limitations that need more in-depth analysis, such as recognizing the immense importance of extrapersonal and sociocultural factors in creativity, which are difficult to prove. In principle, these questions are subject to empirical study; however, the qualitative nature of many aspects of the model may make it possible to accurately test hypotheses. Moreover, the fact that Csikszentmihalyi's model (1996) ambitiously encompasses multiple levels of analysis may create problems in interdisciplinarity, particularly because it is less founded on methodological details. However, this seems to be an unnecessary risk since, as Csikszentmihalyi (1996) argued, for a rich understanding of creativity, many other variables and analysis levels should be considered, such as a quantitative and empirical approach to individual traits, which leads to understanding the nature of creativity.

\section{Vygotsky's Understandment and the Education}

Differently from other authors mentioned until here, Vygotsky $(1990,2004)$ considers that creativity is about combinatory behaviors, that are permeate by previously learnings, recombined to new situations that are show on the environment. The factor surpasses the learnings already consolidated is called by the author as imagination or fantasy and it is through it that the creation happens. Vygotsky $(1990,2004)$ points that the imagination is the base of all the creative activity, permeating all that was create by the human hand: culture, art, science and creative techniques. It can be notice that this author's definition get clearly closer to what is call fluid intelligence. In describing the creativity in childhood, Vygotsky $(1990,2004)$ points that the children, when is playing, not just reproduces what experienced, but reformulate or recreate these experiences, combining such elements according to its needs and desires to create a new reality. In our see, it describes a way of learning. Although there is this approach, Vygotsky (2000), let it clear that does not consider intelligence and creativity the same thing, however independent functions on the psychological development. Another author's important statement about the facts that evolves creation are the emotions. To Vygotsky $(1990,2004)$, the emotions influence flatly on imagination and vice versa. This, by the author, explains the force of the emotional impact that certain artistic works have on people. What ends the circle of the creative operation is the association of imagination with reality, in other words, crystallize in reality what is in the imagined. This crystallization, points the author, don't appears only on the format of technological artifacts but also on artistic works as the literature, for example, that also influence on human behavior. 
With regard to the appliance of this theory to the educational processes, there are possibilities. Vygotsky $(1990,2004)$ considers that creativity is a factor present in all the human beings in bigger or smaller extent and that the social environment that are submitted ends by helping to develop or not the creativity. To Vygotsky (1990, 2004), the most of artifacts used by man over the history produced on earth are by collective creation, in other words, the creativity is fundamental to human survive, then, it should by one of the most important elements to develop in all humans, mainly in education, in any level. Martínez (2002) points that the school is an essential local on development and expression of creativity, requiring of planning of interventions that may develop the creativity and change the school itself too. However, a recent study of Berg et al. (2020) demonstrated that, in Brazil, the higher education (in which one it is expected a pattern to be followed by the other education levels) still there is a lot to produce and understand about creativity, once it is noticed a possible delay on creativity and learning relation. Other authors have been already reported this aspect of creativity in Brazil in other education levels (Wechsler, 2002; Bahia \& Trindade, 2013) pointed that exists barriers to its development. This way, except by some punctual actions as the Waldorf's methodological schools, for example, it could not be clearly affirmed what are the implications of the use of creativity's development to the education on a massive way. Anyway, considering the facts that Vygotsky points about creativity by a dialectical way, we can assume that, using the methods to develop the creativity on education, the learning will be facilitate.

\section{Theory of Creative Investment: The Role of Decision Making}

According to the Theory of Creative Investment, creativity essentially translates into a decision. This conception of creativity suggests that this is a competence that is stimulated, so it can be developed. Simply encouraging students to express their creativity can make them more creative, especially if they believe they will be rewarded for their decision to manifest their creative spirit (O'Hara \& Sternberg, 2000-2001). For someone to be creative, it is fundamental that one is motivated, and one decides to generate new ideas, that later must be analyzed and sold to the public. In other words, a person may evidence synthetic, analytical or practical skills but may not be willing to apply them in solving problems that potentially involve creativity. For example, we may choose to follow ideas that were conceived by others rather than ours; We may not be in the mood to carry out a careful evaluation of ideas; Or we can still assume that other people will not be interested in our ideas, so we do not even choose to express them and try to convince others that they are profitable. We find, therefore, that holding only the ability is not enough. What is indispensable is to make the decision to make good use of this competence. For example, the ability to switch between conventional and non-conventional thinking is an important procedure in expressing creativity. The switch between conventional and nonconventional think- 
ing is a decision and indicates that one is willing to leave the comfort zone for the purpose of thinking in an unusual way. Thus, we may argue that some subjects, designated by Dweck (1999) "entity theorists," prefer to operate primarily or even exclusively in domains that are relatively familiar to them, whereas others, referred to by Dweck (1999) as "theoretical incrementals, new challenges and new conceptual domains". In order to promote creativity, given that it depends to a large extent on personal will, Sternberg (2001) proposed multiple decisions that each individual should take if he or she wishes to develop this competence. Therefore, it emphasized the pertinence of; redefining problems, analyzing issues and assumptions that arise; all the ideas; encourage the production of ideas; recognize that knowledge can favor or hinder creativity; identify and overcome obstacles; take risks in a sensible way; tolerate ambiguity; to believe in oneself (self-efficacy); allow errors; encourage collaboration; accept responsibility for success and failure; invest in their intellectual growth (Sternberg, 2001).

\section{Possible Future Developments in the Study and Intervention in IQ Creativity and Assessment}

There is growing interest in the relationship between video games and creativity (Green \& Kaufman, 2015). Although these formulations are still in the beginning, there are studies that indicate that playing video games contributes to the development of creativity (Fitzgerald et al., 2012; Hamlen, 2011). Researchers (Kim \& Shute, 2015, Kim et al., 2013; Shute \& Ventura, 2013) dedicated themselves to creating a game with the goal of combining learning from physics to creativity. In a playful and educational way, these young people acquire the ability to solve puzzles and have different solutions available to solve their problems. Thus, it is possible to evaluate dimensions such as: fluency, originality and flexibility (Kim \& Shute, 2015). However, it should be noted that the work of Shute \& Ventura (2013), although very recent, results from countless years of continuous development and work. On the other hand, it should be added that the possibilities analyzed above, namely the applicability of the technique of Consensus Evaluation in the area of writing and creativity, are only two possibilities that still require in-depth analyzes in order to verify their validity. The inclusion of new domains, for example creativity, in IQ tests is being seriously considered by some researchers in these areas (creativity and intelligence).

\section{Conclusion}

As such, there is similarity between the aforementioned scientific findings, demonstrating the close relationship between intelligence and creativity, as well as a number of differences that stand out, demonstrating an advance in the thinking and conception of creativity over time. From a scientific standpoint, intelligence and creativity moved beyond being the result of tension between conscious reality and unconscious drives and may even be/have been measured as a form of tacit belief in their existence. All the approaches highlight the impor- 
tance of communication, promotion and optimization of creativity as part of the process (Lubart, 2007).

Science contributed in the form of in-depth studies, with some results remaining valid to date, including Guilford's test and Structure of Intellect and Problem Solving models, as well as studies by Torrance and others (Guilford, 1967, quoted by Kaufman, 2015; Wechsler, 2008; Sternberg, 2001). According to Lubart (2007), this significant progress promoted the need for greater understanding of creative people, their motivations or external traits that influence creativity and foster intelligence.

In the last 20 years, research has concentrated on a cognitive approach and according to Lubart (2007: p. 15), has made it possible to "explore the mental representations as well as the processes of treating and transforming information related to creativity". Thus, the 21 st century is characterized by cognitive creative thinking, which, according to Stoltz (1999, p: 16), includes definitions that encompass "different aspects for its development, with an emphasis on the cultural and social context".

The dimensions recommended by Guilford were broadened and are not exclusively involved in operations, content and products, since, for such divergent and convergent thinking to be set in motion in linear and regressive operations when individuals need to make adjustments, as proposed by Torrance, other intellectual dimensions - synthetic, analytical and practical-contextual-would be required to think and rationalize (Guilford, 1967, quoted by Kaufman, 2015; Wechsler, 2008; Sternberg, 2001).

All of this without considering that personality, cognitive resources and environment as dimensions of confluence, connection or even disposal of hypotheses, possibilities, opportunities or risks, are not directly linked to the legislative style of thinking that, according to Sternberg, is the most common in creative people while executing a task (Sternberg, 2001). As such, creativity and intelligence are connected, and a certain intellectual level can be predicted to establish creative thinking. Additionally, the mental dynamic is more complex in terms of the synergy between both, and we can disregard the notion that simple linear mapping of a thought during a task would reach the heart of the question.

The evolution of creative thinking and intelligence from a systemic standpoint is also evident (Csikszentmihalyi, 1996), primarily with respect to recognizing the importance of extrapersonal and sociocultural factors in creativity and intelligence and linking them to intrapersonal aspects, as well as contributing to the cause and cognitive effect relationship for both the happiness existing in the intellect and creativity that arise from executing the task.

Studies seem to show that the future of creativity in intellectuality lies in transcending the systematic and cognitive vision, thereby leading to quantum thinking, aligning points as yet not understood, associated with awareness and existence itself. In this respect, if we wish to participate in forming creative young people who think and commit themselves critically to science and intelligent and innovative solutions for sustainable change, the education system must cooperate 
assertively with its universities in an atmosphere of mutual respect.

According to Pineda-López et al. (2019), universities need to undergo professional training and cognitive development in order to develop citizens capable of collective creativity with a humanistic perspective in order to achieve paradigmatic change. There is a need to improve and synergize what the area already possesses-tests, assessments, mappings, models, methods etc.-with the environment and human reality. The knowledge acquired needs to reach the school setting, focusing on teacher training and other improvements (Suárez \& Wechsler, 2019).

As such, it is urgent that the theoretical evidence synthesized here serve as a guide to create public policies that result in greater investment in education. It is believed that both intelligence and creativity have an epistemological connection capable of directly affecting educational contexts, resulting in education founded on a new paradigm of thinking that seeks what is to come and raises consciousness.

\section{Conflicts of Interest}

The authors declare no conflicts of interest regarding the publication of this paper.

\section{References}

Albert, R. S. (1996). Some Reasons Why Childhood Creativity Often Fails to Make It Past Puberty into the Real World. In M. A. Runco (Ed.), Creativity from Childhood through Adulthood. New Directions for Child Development (No. 72, pp. 43-56). San Francisco, CA: Jossey-Bass. https://doi.org/10.1002/cd.23219967205

Amabile, T. M. (1996). Creativity in Context. Boulder, CO: Westview Press.

Anthony, S. H., Fioratou, E., Gilhooly, K. J., \& Wynn, V. (2007). Divergent Thinking: Strategies and Executive Involvement in Generating Novel Uses for Familiar Objects. British Journal of Psychology, 98, 611-625. https://doi.org/10.1111/j.2044-8295.2007.tb00467.x

Arendasy, M., Benedek, M., Jauk, E., Neubauer, A. C., \& Sommer, M. (2014). Intelligence, Creativity, and Cognitive Control: The Common and Differential Involvement of Executive Functions in Intelligence and Creativity. Intelligence, 46, 73-83. https://doi.org/10.1016/j.intell.2014.05.007

Baer, J., \& Kaufman, J. C. (2006). Intelligent Testing with Torrance. Creativity Research Journal, 18, 99-102. https://doi.org/10.1207/s15326934crj1801_11

Baer, J., \& Kaufman, J. C. (2012). Beyond New and Appropriate: Who Decides What Is Creative? Creativity Research Journal, 24, 83-91. https://doi.org/10.1080/10400419.2012.649237

Baer, J., Cole, J. C., \& Kaufman, J. C. (2009). Expertise, Domains, and the Consensual Assessment Technique. Journal Creative Behavior, 43, 223-233. https://doi.org/10.1002/j.2162-6057.2009.tb01316.x

Baer, J., Kaufman, J. C., Lee, J., \& Lee, S. (2007). Captions, Consistency, Creativity, and the Consensual Assessment Technique: New Evidence of Validity. Thinking Skills and Creativity, 2, 96-106. https://doi.org/10.1016/j.tsc.2007.04.002

Bahia, S. (2008). Promoção de ethos criativos. In Morais, F., \& Bahia S. (Eds). Criatividade e educação: Conceitos, necessidades e intervenção (pp. 229-250). Braga: Psiquilibrios. 
Bahia, S., \& Moreno, J. (2007). Ostalentos de umasociedadesemtalento. Cadernos Sociedade e Trabalho. Integração das Pessoas com Deficiência, 8, 165-180.

Bahia, S., \& Trindade, J. P. (2013). Transformar o velhoem novo: Aintegração da criatividadenaeducação. In F. H. R. Piske, \& S. Bahia (Eds.), Criatividade na escola: $O$ desenvolvimento de potencialidades, altas habilidades/superdotação (AH/SD) e talentos. $\mathrm{Cu}-$ ritiba: Juruá.

Batey, M., \& Furnham, A. (2006). Creativity, Intelligence, and Personality: A Critical Review of the Scattered Literature. Genetic, Social, and General Psychology Monographs, 132, 355-429. https://doi.org/10.3200/MONO.132.4.355-430

Beaty, R. E., \& Silvia, P. J. (2013). Metaphorically Speaking: Cognitive Abilities and the Production of Figurative Language. Memory \& Cognition, 41, 255-267. https://doi.org/10.3758/s13421-012-0258-5

Berg, J., Vestena, C. L. B., \& Costa-Lobo, C. (2020). Creativity in Brazilian Education: Review of a Decade of Literature. Creative Education, 11, 420-433. https://doi.org/10.4236/ce.2020.113030

Cramond, B., \& Torrance, E. P. (2002). Needs of Creativity Programs, Training, and Research in the Schools of the Future. Research in the Schools, 9, 5-14.

Csikszentmihalyi, M. (1996). Creativity: Flow and the Psychology of Discovery and Invention. New York: Harper Perennial.

Csikszentmihalyi, M. (2014). The Systems Model of Creativity. Claremont: Springer. https://doi.org/10.1007/978-94-017-9085-7

Cunha, A. M. S. (2011). Emoção e Cognição no Desenvolvimento de Alunos com Altas Habilidades/Superdotados. Revista Lugares da Educação, 1, 107-122.

https://doi.org/10.18788/2237-1451/rle.v1n1p107-122

De Boeck, P., \& Partchev, I. (2012). IRTrees: Tree-Based Item Response Models of the GLMM Family. Journal of Statistical Software, 48, 1-28. https://doi.org/10.18637/jss.v048.c01

Dollinger, S. J. (2007). Creativity and Conservatism. Personality and Individual Differences, 43, 1025-1035. https://doi.org/10.1016/j.paid.2007.02.023

Dweck, C. S. (1999). Self-Theories: Their Role in Motivation, Personality, and Development. Philadelphia, PA: Psychology Press/Taylor \& Francis.

Faria, L. (2007). Teorias implícitas da inteligência: Estudos no contexto escolar português. Paidéia, 12, 93-103. https://doi.org/10.1590/S0103-863X2002000200007

Fink, A., Slamar-Habedl, M., Unterrainer, H. F., \& Weiss, E. M. (2012). Creativity: Genius, Madness or a Combination of Both? Psychology of Aesthetics, Creativity and the Arts, 6, 11-18. https://doi.org/10.1037/a0024874

Fitzgerald, H. E., Games, A. I., Jackson, L. A., Von Eye, A., Witt, E. A., \& Zhao, Y. (2012). Information Technology Use and Creativity: Findings from the Children and Technology Project. Computers in Human Behavior, 28, 370-376.

https://doi.org/10.1016/j.chb.2011.10.006

Fleith, D. S., \& Alencar, E. S. (2005). Escala sobre o clima para criatividade em sala de aula. Psicologia: Teoria e Pesquisa, 21, 85-91. https://doi.org/10.1590/S0102-37722005000100012

Forthmann, B., Holling, H., Çelik, P., Storme, M., \& Lubart, T. (2017). Typing Speed as a Confounding Variable and the Measurement of Quality in Divergent Thinking. Creativity Research Journal, 29, 257-269. https://doi.org/10.1080/10400419.2017.1360059

Forthmann, V., Burkner, P., Szardenings, C., Benedek, M., \& Holling, H. (2019). A New Perspective on the Multidimensionality of Divergent Thinking Tasks. Frontiers in Psychology, 10, 985. https://doi.org/10.3389/fpsyg.2019.00985 
Friedman, N. P., \& Miyake, A. (2012). The Nature and Organization of Individual Differences in Executive Functions: Four General Conclusions. Current Directions in Psychological Science, 21, 8-14. https://doi.org/10.1177/0963721411429458

Furnham, A., Batey, M., Anand K., \& Manfield, J. (2008). Personality, Hypomania, Intelligence and Creativity. Personality and Individual Differences, 44, 1060-1069. https://doi.org/10.1016/j.paid.2007.10.035

Getzels, J. W., \& Jackson, P. W. (1962). Creativity and Intelligence: Exploration with Gifted Students. New York: John Wiley \& Sons.

Getzels, J., \& Csikszentmihalyi, M. (1976). The Creative Vision: A Longitudinal Study of Problem Finding in Art. New York: Wiley.

Gómez, M. S. (2010). Creatividad, Personalidad y Competencia Socio-emocional en Alumnos de Altas Habilidades versus no Altas Habilidades. Dissertação de Doutoramento não publicada, Murcia: Universidad de Murcia.

Green, G. P., \& Kaufman, J. C. (2015). Videogames and Creativity. San Diego, CA: Academic Press.

Gross, M. U. M. (2014). Issues in the Social-Emotional Development of Intellectually Gifted Children. InF. H. R. Piske, J. M. Machado, S. Bahia, \& T. Stoltz (Eds.) Altas Habilidades/Superdotação (AH/SD): Criatividade e emoção (pp. 120-139). Curitiba: Juruá.

Guenther, Z. C. (2000). Educando bem dotados: Algumas ideias básicas. In L. Almeida, E. P. Oliveira, \& A. S. Melo (Eds.), Alunos sobredotados: Contributos para a sua identificação e apoio (pp. 11-18). Braga: ANEIS.

Guignard, J. H. \& Zenasni, F. F. (2009). Les Caractéristiques Émotionnelles des Enfants à Haut Potentiel. Psychologie Française, 4, 304-319.

Guilford, J. P. (1967). The Nature of Human Intelligence. New York: McGraw-Hill.

Haensly, P. A., \& Reynolds, C. R. (1989). Creativity and Intelligence. In J. A. Glover, R. R. Ronning, \& C. R. Reynolds (Eds.). Handbook of Creativity (pp. 111-132). New York: Plenum Press.

Hamlen, K. (2011). Children's Choices and Strategies in Video Games. Computers in Human Behavior, 27, 532-539. https://doi.org/10.1016/j.chb.2010.10.001

Hass, R. W. (2015). Feasibility of Online Divergent Thinking Assessment. Computers in Human Behavior, 46, 85-93. https://doi.org/10.1016/j.chb.2014.12.056

Jung, R. E. (2014). Evolution, Creativity, Intelligence, and Madness: "Here Be Dragons". Frontiers in Psychology, 5, 784. https://doi.org/10.3389/fpsyg.2014.00784

Kane, M. \& Silverman, L. K. (2014). Fostering Well-Being in Gifted Children: Preparing for a Uncertain Future. In F. H. R. Piske, J. M. Machado, S. Bahia, \& T. Stoltz (Eds.), Altas habilidades/Superdotacao (AH/SD): Criatividade e emocao (Giftedness: Creativity and Emotion) (pp. 67-84). Curitiba: Juruá.

Karwowski, M., Dul, J., Gralewski, J., Jauk, E., Jankowska, D. M., Gajda, A. et al. (2016). Is Creativity without Intelligence Possible? A Necessary Condition Analysis. Intelligence, 57, 105-117. https://doi.org/10.1016/j.intell.2016.04.006

Kaufman, A. S. (2009). IQ Testing 101. New York: Springer Publishing Company.

Kaufman, A. S. (2013a). Intelligent Testing with Wechsler's Fourth Editions: Perspectives on the Weiss et al. Studies and the Eight Commentaries. Journal of Psychoeducational Assessment, 31, 224-234. https://doi.org/10.1177/0734282913478049

Kaufman, J. C. (2012). Counting the Muses: Development of the Kaufman-Domains of Creativity Scale (K-DOCS). Psychology of Aesthetics, Creativity, and the Arts, 6, 298-308. https://doi.org/10.1037/a0029751 
Kaufman, J. C. (2015). Why Creativity Isn't in IQ Tests, Why It Matters, and Why It Won't Change Anytime Soon Probably. Journal of Intelligence, 3, 59-72. https://doi.org/10.3390/jintelligence3030059

Kim, K. H. (2008). Meta-Analyses of the Relationship of Creative Achievement to Both IQ and Divergent Thinking Test Scores. The Journal of Creative Behavior, 42, 106-130. https://doi.org/10.1002/j.2162-6057.2008.tb01290.x

Kim, K. H., Cramond, B., \& Bandalos, D. L. (2006). The Latent Structure and Measurement Invariance of Scores on the Torrance Tests of Creative Thinking Figural. Educational and Psychological Measurement, 66, 459-477. https://doi.org/10.1177/0013164405282456

Kim, Y. J., \& Shute, V. J. (2015). Opportunities and Challenges in Assessing and Supporting Creativity in Video Games. In G. P. Green, \& J. C. Kaufman (Eds.), Videogames and Creativity (pp. 99-117). San Diego, CA: Academic Press. https://doi.org/10.1016/B978-0-12-801462-2.00005-9

Kim, Y. J., Shute, V. J., \& Ventura, M. (2013). Assessment and Learning of Informal Physics in Newton's Playground. The Journal of Educational Research, 106, 423-430. https://doi.org/10.1080/00220671.2013.832970

Krentzman, A. R. (2013). Review of the Application of Positive Psychology to Substance Use, Addiction, and Recovery Research. Psychology of Addictive Behaviors, 27, 151-165. https://doi.org/10.1037/a0029897

Lubart, T. (2007). Psicologia da Criatividade. Porto Alegre: Artmed.

Martindale, C. (1999). Biological Bases of Creativity. In R. J. Sternberg (Ed.), Handbook of Creativity (pp. 137-152). Cambridge: Cambridge University Press. https://doi.org/10.1017/CBO9780511807916.009

Martínez, A. M. (2002). A criatividade na escola: Três direções de trabalho. Linhas Críticas, 8, 189-206. https://doi.org/10.26512/lc.v8i15.3057

Nakano, T. C., Wechsler, S. M., \& Primi, R. (2011). Teste de criatividade figural infantil. São Paulo: Vetor.

Nakano, T. C., Wechsler, S. M., Campos, C. R., \& Milian, Q. G. (2015). Intelligence and Creativity: Relationships and Their Implications for Positive Psychology. Psico-USF, 20, 195-206. https://doi.org/10.1590/1413-82712015200201

Neumann, P., \& Vestena, C. L. B. (2016). A relação entre idade e inteligência emocional em adultos com Altas Habilidades/superdotação. Revista Diálogos e Perspectivas em Educação Especial, 3, 77-94. https://doi.org/10.36311/2358-8845.2016.v3n1.08.p77

Nusbaum, E. C., \& Silvia, P. J. (2011). Are Intelligence and Creativity Really So Different? Fluid Intelligence, Executive Processes, and Strategy Use in Divergent Thinking. Intelligence, 39, 36-45. https://doi.org/10.1016/j.intell.2010.11.002

O’Hara, L. A., \& Sternberg, R. J. (2000-2001). It Doesn't Hurt to Ask: Effects of Instructions to Be Creative, Practical, or Analytical on Essay-Writing Performance and Their Interaction with Students' Thinking Styles. Creativity Research Journal, 13, 197-210. https://doi.org/10.1207/S15326934CRJ1302_7

Oliveira, C. S., \& Vestena, C. L. B. (2017). Processo criativo de superdotados: Sujeito epistêmico, diagnóstico e considerações educacionais. São Paulo: Novas Edições Acadêmicas.

Padilla, A., Hogan, R., \& Kaiser, R. B. (2007). The Toxic Triangle: Destructive Leaders, Susceptible Subordinates, and Conducive Environments. The Leadership Quarterly, 18, 176-194. https://doi.org/10.1016/j.leaqua.2007.03.001

Peterson, J. (2014). Paying Attention to the Whole Gifted Child: Why, When and How to Focus on Social and Emotional Development. In F. H. R. Piske, J. M. Machado, S. Ba- 
hia, \& T. Stoltz (Eds.), Altas Habilidades/Superdotação (AH/SD): Criatividade e emoção (pp. 45-65). Curitiba: Juruá.

Piaget, J. (1918). Recherche. Laussane: La Concorde.

Piaget, J. (1932). O julgamento moral na criança. São Paulo: Editora Mestre Jou.

Piaget, J. (1986) O nascimento da inteligência da criança. São Paulo: Editora Crítica.

Pineda-López, M. R., Sánchez-Velásquez, L. R., Alarcón-Gutiérrez, E., \& Ruiz Cervantes, E. E. (2019). La formación de científicos creativos con perspectiva regional en las universidades públicas: Un reto. Diálogos sobre Educación. Temas Actuales en Investigación Educativa, 10, 1-11.

Piske, F. H. R. (2014). Criatividade e inovação na educação de superdotados. InF. H. R. Piske, J. M. Machado, S. Bahia, \& T. Stoltz (Eds.), Altas Habilidades/Superdotação (AH/SD): Criatividade e emoção (pp. 89-92). Curitiba: Juruá.

Piske, F. H. R. (2016). Alunos com Altas Habilidades/Superdotação (AH/SD): Como identificá-los? In F. H. R. Piske et al. (Eds.), Altas Habilidades/Superdotação (AH/SD) e Criatividade: Identificação e Atendimento. Curitiba: Juruá.

Piske, F. H. R., Stoltz, T., Machado, J. M., Vestena, C. L. B., de Oliveira, C. S., de Freitas, S. P., \& Machado, C. L. (2016a). Working with Creativity of Gifted Students through Ludic Teaching. Creative Education, 7, 1641-1647.

https://doi.org/10.4236/ce.2016.711167

Piske, F. H. R., Stoltz, T., Vestena, C. L. B., de Freitas, S. P., Valentim, B. de F. B., de Oliveira, C. S., Barby, A. A. de O. M., \& Machado, C. L. (2016b). Barriers to Creativity, Identification and Inclusion of Gifted Student. Creative Education, 7, 1899-1905. https://doi.org/10.4236/ce.2016.714192

Plucker, J. A., Beghetto, R. A., \& Dow, G. T. (2004). Why Isn't Creativity More Important to Educational Psychologists? Potentials, Pitfalls, and Future Directions in Creativity Research. Educational Psychologist, 39, 83-96. https://doi.org/10.1207/s15326985ep3902_1

Powell, M. C. (1994). On Creativity and Social Change. Journal of Creative Behavior, 28, 21-32. https://doi.org/10.1002/j.2162-6057.1994.tb00717.x

Priest, T. (2006). Self-Evaluation, Creativity, and Musical Achievement. Psychology of Music, 34, 47-61. https://doi.org/10.1177/0305735606059104

Prieto, M. F. (2006). Creatividad e Inteligencia Emocional. Un estudio empírico en alumnos con altas habilidades. Dissertação de Doutoramento não Publicada, Murcia: Universidade de Murcia.

Reis, S. M., Gubbins, J., Briggs, C. J., Schreiber, F. J., Richards, S., Jacobs, J. K., Eckert, R. D., \& Renzulli, J. S. (2004). Reading Instruction for Talented Readers: Case Studies Documenting Few Opportunities for Continuous Progress. Gifted Child Quarterly, 48, 315-338. https://doi.org/10.1177/001698620404800406

Runco, M. A. (2014). Creativity. Theories and Themes: Research, Development and Practice. Amsterdam: Elsevier.

Runco, M. A., \& Acar, S. (2012). Divergent Thinking as an Indicator of Creative Potential. Creativity Research Journal, 24, 66-75. https://doi.org/10.1080/10400419.2012.652929

Shute, V. J., \& Ventura, M. (2013). Stealth Assessment: Measuring and Supporting Learning in Games: Stealth Assessment. Cambridge, MA: MIT Press. https://doi.org/10.7551/mitpress/9589.001.0001

Silvia, P. J. (2008a). Another Look at Creativity and Intelligence: Exploring Higher-Order Models and Probable Confounds. Personality and Individual Differences, 44, 1012-1021. https://doi.org/10.1016/j.paid.2007.10.027 
Silvia, P. J. (2008b). Creativity and Intelligence Revisited: A Latent Variable Analysis of Wallach and Kogan (1965). Creativity Research Journal, 20, 34-39. https://doi.org/10.1080/10400410701841807

Silvia, P. J. (2015). Intelligence and Creativity Are Pretty Similar after All. Educational Psychology Review, 27, 599-606. https://doi.org/10.1007/s10648-015-9299-1

Sternberg, R. (2008). Psicologia cognitiva (4th ed.). Porto Alegre: Artmed.

Sternberg, R. J. (1988). Mental Self-Government: A Theory of Intellectual Styles and Their Development. Human Development, 31, 197-224. https://doi.org/10.1159/000275810

Sternberg, R. J. (1997b). Successful Intelligence. New York: Plume.

Sternberg, R. J. (2001). What Is the Common Thread of Creativity? Its Dialectical Relation to Intelligence and Wisdom. American Psychologist, 56, 360-362. https://doi.org/10.1037/0003-066X.56.4.360

Sternberg, R. J., \& Grigorenko, E. L. (1995). Styles of Thinking in School. European Journal of High Ability, 6, 201-219. https://doi.org/10.1080/0937445940060211

Sternberg, R. J., \& Lubart, T. I. (1991). An Investment Theory of Creativity and Its Development. Human Development, 34, 1-31. https://doi.org/10.1159/000277029

Sternberg, R. J., \& Lubart, T. I. (1995). Defying the Crowd: Cultivating Creativity in a Culture of Conformity. New York: Free Press.

Sternberg, R., \& Lubart, T. (2009). The Concept of Creativity: Prospects and Paradigms. In R. Sternberg (Ed.), Handbook of Creativity (pp. 3-15). Cambridge: Cambridge University Press. https://doi.org/10.1017/CBO9780511807916.003

Sternberg, R., \& O’Hara, L. (2009). Creativity and Intelligence. In R. Sternberg (Ed.), Handbook of Creativity (pp. 251-272). Cambridge: Cambridge University Press. https://doi.org/10.1017/CBO9780511807916.015

Sternberg, R., O’Hara, L., \& Lubart, T. (1997). Creativity as Investment. California Management Review, 40, 8-21. https://doi.org/10.2307/41165919

Stoltz, T. (1999). Capacidade de Criação. Petrópolis: Vozes.

Stoltz, T. (2016). Imaginação e Criatividade na Educação: a Necessidade de Outro Olhar. In F. H. R. Piske et al. (Eds.), Altas Habilidades/Superdotação (AH/SD) e Criatividade: Identificação e Atendimento. Curitiba: Juruá.

Suárez, J. T., \& Wechsler, S. M. (2019). Identification of Creative and Intellectual Talent in the Classroom. Psicologia Escolar e Educacional, 23, e192483. https://doi.org/10.1590/2175-35392019012483

Torrance, E. P. (1965). Rewarding Creative Behavior. Englewood Cliffs, NJ: Prentice-Hall.

Torrance, E. P. (2001). Test Developer Profiles: E. Paul Torrance. http://www.mhhe.com/mayfieldpub/psychtesting/profiles/torrance.htm

Torrance, E. P. (2008). The Torrance Tests of Creative Thinking Norms-Technical Manual Figural (Streamlined) Forms A \& B. Bensenville, IL: Scholastic Testing Service.

Valentim, B. F. B., Vestena, C. L. B., \& Neumann, P. (2014). Educadores e estudantes: Um olhar para a afetividade nas Altas Habilidades/Superdotação. Revista Educação Especial, 27, 713-723. https://doi.org/10.5902/1984686X14421

Vygotsky, L. S. (1990). Imagination and Creativity in Childhood. Soviet Psychology, 28, 84-96. https://doi.org/10.2753/RPO1061-0405280184

Vygotsky, L. S. (2000). Imaginación y creatividad del adolescente. In Obras Escogidas. Tomo IV. Psicologia Infantil (pp. 205-233). Madrid: Antonio Machado Libros. 
Vygotsky, L. S. (2004). Imagination and Creativity in Childhood. Journal of Russian and East European Psychology, 42, 7-97. https://doi.org/10.1080/10610405.2004.11059210

Wallach, M. A., \& Kogan, N. (1965). Modes of Thinking in Young Children: A Study of the Creativity-Intelligence Distinction. New York: Holt, Rinehart \& Winston.

Ward, T. B. (1994). Structured Imagination: The Role of Conceptual Structure Ill Exemplar Generation. Cognitive Psychology, 27, 1-40.

https://doi.org/10.1006/cogp.1994.1010

Wechsler, S. M. (2002). Criatividade e desempenho escolar: Uma síntese necessária. Linhas Críticas, 8, 179-188. https://doi.org/10.26512/lc.v8i15.3056

Wechsler, S. M. (2008). Criatividade: Descobrindo e Encorajando. Campinas: LAMP/IDB. 